Communist China. “. . . it is apparent that within the next ten years China's needs will be so great (both absolutely and relative to her resources) that she may constitute a major market for exports from other areas". We may also find that Communist China will become a competitor through its export of forest products since ... "much of China's forest resource (in the northeast) is closer and more readily accessible to the major markets of east Asia than to her own domestic centers of consumption; and, secondly, the development of major wood-processing industries in China (to meet her enormous domestic requirements) could well allow exportable margins, even if based on the processing of imported raw materials."

The problems of human biology implicit in a net increase of 26.6 per minute and the need to find 0.05 cubic meters of forest products for each person in Communist China are of concern to all of us. Dr. Richardson has provided a valuable introduction to the forests of Communist China. I hope that his work will be followed by studies of other foresters who also are interested in telling the World what is going on behind the bamboo curtain, and that ideology will not stifle investigation.

J. H. G. SMITH

\title{
Association of British Columbia Foresters' Elections
}

At the eighteenth annual meeting of the 420-member Association of British Columbia Foresters, held in Vancouver February 3-4, 1966, W. Edward L. Young, i/c Surveys Division, B.C. Forest Service, Victoria, was elected President. He succeeds Robert S. Wood, Manager, Timber Planning, Weldwood of Canada Ltd., who becomes Past President.

Vice-President is Donald W. Smith, Consulting Forester, Victoria. Also re-elected to Council is Robert E. Breadon, Director, U.B.C. Research Forest, Haney.

Newly elected councillors are:

Philip B. Bodman, Industrial Forestry Service Ltd., Prince George;

Robert B. Fisher, Director and Woodlands Manager, L \& K Lumber Ltd. (North Shore) Ltd., North Vancouver;

Edward Knight, B.C. Forest Service, Victoria;

Allan C. Schutz, B.C. Forest Service, Vancouver.

F. M. Knapp, Professor Emeritus of Forestry, U.B.C., was re-appointed Registrar. 